\title{
Gotyckie malowidło z Ukrzyżowaniem w kościele Wniebowzięcia Najświętszej Marii Panny w Toruniu w świetle najnowszych badań
}

\author{
JULIUSZ RACZKOWSKI \\ Wydział Sztuk Pięknych, UMK w Toruniu \\ e-mail: jracz@umk.pl \\ ORCID: 0000-0003-3081-8615
}

Keywords: gothic, wall painting, the Franciscans, Torun

Słowa kluczowe: gotyk, malarstwo ścienne, franciszkanie, Toruń

\begin{abstract}
Gothic Wall Painting with the Crucifixion in the Church of the Assumption of the Blessed Virgin Mary in Torun in the Light of Recent Studies

This paper presents the results of recent studies (stylistic analysis and non-destructive testing) of the painting located in the first Eastern span of the ground floor of the northern aisle (former cloister) in the church of the Assumption of the Blessed Virgin Mary in Torun. Regardless of the poor state of preservation of the painting, of which just the general outlines are recognizable, there are two subsequent chronological layers visible, detectable also by the near infrared and UV-induced fluorescence analyses. The younger layer can be dated back to the late $14^{\text {th }}$ century, which is indicated by its typology (the image of the Crucified) and by its general stylistic features rooted in Bohemian art; the older layer can be dated to the first half of $14^{\text {th }}$ century. The painting made a part of decoration of the brothers' space (with possible access of lay people). Its original function is not known. Surely, it documents the existence of the Passion cult with strong Eucharistic colouring as well as to the Franciscan observances (processional liturgy?). It also makes a proof of actualisation of the interior décor and of the transmission of Bohemian patterns in late $14^{\text {th }}$ century.
\end{abstract}




\begin{abstract}
Abstrakt
Artykuł przedstawia rezultaty nowego rozpoznania (badania stylistyczne i techniki nieniszczące) malowidła w pierwszym od wschodu przęśle przyziemia nawy północnej (dawny krużganek) w kościele Wniebowzięcia NMP w Toruniu. Choć malowidło jest słabo zachowane i widoczne tylko w ogólnym zarysie, czytelne są dwie kolejne warstwy chronologiczne, rozpoznawalne także w fotografii w bliskiej podczerwieni i fluorescencji wzbudzanej UV. Warstwę młodszą można datować na koniec XIV w., na co wskazuje typologia (wizerunek Ukrzyżowanego) oraz ogólne cechy stylowe osadzone w sztuce czeskiej; warstwa starsza może pochodzić z 1. połowy XIV w. Obraz należał do wystroju przestrzeni brackiej (z możliwym dostępem ludzi świeckich). Jego pierwotna funkcja nie jest znana. Z pewnością dokumentuje kult pasyjny z silnym zabarwieniem eucharystycznym, a także obrzędowość franciszkańską (liturgia procesyjna?). Jest też dowodem aktualizacji wystroju wnętrza oraz transmisji wzorców czeskich pod koniec XIV w.
\end{abstract}

Gotyckie malowidło ścienne ze sceną Ukrzyżowania, odkryte w 1971 roku podczas prac konserwatorskich prowadzonych w północnej części kościoła pw. Wniebowzięcia Najświętszej Marii Panny w Toruniu, jest jedynym średniowiecznym przedstawieniem figuralnym zachowanym w wystroju przyziemia nawy północnej (dawnego południowego skrzydła krużganka klasztoru toruńskich franciszkanów). Umieszczone w pierwszym przęśle od wschodu, w pobliżu wejścia do nawy głównej (il. 1:a-b), zakomponowane jest dość oszczędnie: ukazuje ukrzyżowanego Chrystusa w asyście Marii Bolesnej i św. Jana Ewangelisty oraz czterech drobnych postaci anielskich w górnej części obrazu (il. 2). Zabytek przetrwał w bardzo złym stanie - rozpoznawalny jest jedynie ogólny zarys kompozycji i główne plamy barwne bez opracowania malarskiego (modelunku wykończeniowego) ${ }^{1}$. Część górna przedstawienia uległa uszkodzeniu podczas wkucia instalacji radiofonicznej w $1950 \mathrm{roku}^{2}$, jego dolna partia jest zupełnie spudrowana i przetarta, a powierzchnia wykazuje liczne ubyt-

1 Obraz jest silnie przetarty na całej powierzchni, modelunek światłocieniowy - zatracony, nie zachowały się żadne szczegóły; gdzieniegdzie przebijają ślady rysunku kompozycyjnego. Dolna partia kompozycji jest całkowicie nieczytelna, w świetle widzialnym nie można rozpoznać, czy u stóp krzyża znajdowały się dodatkowe motywy ikonograficzne.

2 Ryszard Żankowski i Krzysztof Owsiany, „Krużganek północny w kościele NM Panny w Toruniu. Spostrzeżenia i propozycje konserwatorskie. Program prac konserwatorskich, opracowano na zlecenie Konserwatora Miejskiego w Toruniu, Toruń, 2 kwietnia 1993 r.” (dokumentacja konserwatorska, Toruń 1993, Archiwum Biura Miejskiego Konserwatora Zabytków w Toruniu), 23. Ingerencja ta dotknęła najistotniejszej partii kompozycji, w miejscu twarzy Chrystusa znajduje się łata. 
ki (il. 3), zarysowania i spękania (il. 4). Trudno zatem oceniać cechy stylu, związki warsztatowe i poziom artystyczny dzieła, lecz sama jego obecność w przestrzeni dawnego krużganka zasługuje na odnotowanie i próbę interpretacji. Tymczasem - zapewne z uwagi na zły stan zachowania - malowidło nie budziło dotąd większego zainteresowania badawczego i pozostaje w zasadzie nieznane, do czego przyczyniło się też jego stosunkowo późne odkrycie ${ }^{3}$ i wprowadzenie do literatury dopiero w latach osiemdziesiątych XX wieku. Skromny stan badań, ograniczający się do wzmianek (na ogół w ramach enumeracji innych malowideł w kościele Mariackim $)^{4}$, uzupełniają niepublikowane obserwacje na temat techniki wykonania, jakie przy okazji prac badawczych w krużganku poczynili Ryszard Żankowski i Krzysztof Owsiany5. Niniejszy komunikat przedstawia wyniki niedawnych prac badawczych przeprowadzonych przy zabytku w ramach projektu NPRH „Inwentarz sztuki Torunia”. Analizy styloznawcze oraz ikonograficzne zostały wsparte specjalistyczną dokumentacją fotograficzną (IR, UV) i badaniami nieniszczącymi (XRF) ${ }^{6}$, które pozwalają podjąć ostrożną próbę datowania tego dzieła i wskazania na jego artystyczne pierwowzory. Należy podkreślić, że przedstawione tu wstępne rozpoznanie jest jedynie próbą interpretacji szczątkowo zachowanego dzieła opartą na dostępnej dziś metodyce i nie rozstrzyga wszystkich wątpliwych kwestii.

Omawiane malowidło znajduje się na skośnej ściance występu muru w pierwszym od wschodu przęśle dawnego skrzydła krużganka, w pobliżu portalu-łącznika prowadzącego do nawy głównej ze strefy klasztornej (il. 5). Jest to samodzielna kompozycja z własnym tłem i bordiurą, „zawieszona”

3 Nie zachowała się niestety dokumentacja tych prac.

4 Obraz przywołano zaledwie parokrotnie, a wiedza o nim ogranicza się do propozycji datowania w ramach większych zespołów malowideł zachowanych w kościele. Nie podjęto żadnych prób określenia typu, stylu i proweniencji ani uargumentowania proponowanej metryki. Zob. Jerzy Domasłowski, „Polska północno-wschodnia,” w Materiały do katalogu gotyckich malowideł ściennych $w$ Polsce, red. Alicja Karłowska-Kamzowa (Poznań: Wydawnictwo Naukowe UAM, 1981), 58 (dat. 1380-1390); Jerzy Domasłowski i Jarosław Jarzewicz, Kościół Najświętszej Marii Panny w Toruniu (Zabytki Polski Północnej nr 10) (Toruń: TNT, 1998), 100 (III faza dekoracji krużganku, k. XIV w.); Jerzy Domasłowski, „Kościół Wniebowzięcia NMP w Toruniu," w Malarstwo gotyckie w Polsce (Dzieje Sztuki Polskiej 2, cz. 3), red. Adam Labuda i Krystyna Secomska, t. 2 Katalog (Warszawa: DiG, 2004), 103 (dat. 1380-1390); Monika Jakubek-Raczkowska, „Tu ergo flecte genua tua”. Sztuka a praktyka religijna świeckich $w$ diecezjach pruskich państwa zakonu krzyżackiego do połowy XV wieku (Pelplin: Bernardinum, 2014), il. 58b - autorka wprawdzie nie wymieniła malowidła, ale zamieściła jego reprodukcję, jak dotąd jedyną w literaturze.

5 Zob. Żankowski i Owsiany, „Krużganek północny,” 22-24.

6 Dokumentację i badania wykonał autor. 
obecnie na tle ornamentalnej, roślinnej polichromii tego przęsła (efekt jest wtórny, gdyż ornamentykę wprowadzono na ściany i sklepienie w kolejnej warstwie chronologicznej). Malowidło zostało umieszczone na wysokości około $50 \mathrm{~cm}$ od obecnego poziomu posadzki, a około $110 \mathrm{~cm}$ ponad jej poziomem pierwotnym ${ }^{7}$. Prostokątne pole obrazowe o wymiarach około $202 \times 130 \mathrm{~cm}$ jest nieregularne, gdyż zostało dokładnie dostosowane do kształtu ścianki; również powierzchnia malowidła wykazuje liczne nierówności. Obraz jest namalowany temperą na niedbale wygładzonym, twardym tynku z drobnoziarnistym wypełniaczem, bez zastosowania pobiały ${ }^{8}$, co jest dość rzadkim rozwiązaniem technicznym na tle tradycji średniowiecznego malarstwa ściennego w Toruniu i w państwie zakonnym w Prusach ${ }^{9}$. Warstwa ta została naniesiona na skośną ściankę w niewielkim fragmencie ${ }^{10}$, specjalnie pod to malowidło, niezależnie od kilku wcześniejszych warstw technologicznych, zachowanych do dziś na murach wschodniego przęsła ${ }^{11}$. Pod nią znajdują się relikty jeszcze wcześniejszego tynku z warstwami malarskimi, które są jednak zupełnie nieuchwytne ${ }^{12}$.

Choć malowidło zachowało się tylko w ogólnym zarysie, czytelne są przynajmniej dwie nakładające się na siebie, średniowieczne warstwy chronologiczne. Charakterystyczna niezborność zdwojonych gdzieniegdzie konturów kompozycji (np. w partii krzyża, głów, nimbów) nie jest najpewniej wynikiem „korekt autorskich”, lecz efektem przenikania się kompozycji z dwóch faz, co uwydatnia również dokumentacja w bliskiej podczerwieni oraz UV (il. 6: a, b). Warstwa przemalowania, zapewne o znacznie słabszej przyczepności, uległa daleko idącemu przetarciu i spudrowaniu, odsłaniając zarys swojej poprzedniczki (il. 7). Została ona położona w miarę dokładnie w obrębie starszej warstwy i powtarza zasadniczo jej strukturę kompozycyjną, zmieniając jednak proporcje postaci i niektóre szczegóły układu. Ta rzucająca się w oczy dwu-

7 Obecna posadzka jest względem pierwotnego poziomu znacznie podwyższona - w wyniku prac w 1824 r. oraz działań konserwatorskich z lat 70. i 90. XX w.

8 Żankowski i Owsiany, „Krużganek północny,” 27-28, sugerowali podmalowanie al fresco.

9 Do nielicznych wyjątków zalicza się jedynie obraz wotywny z k. XIV w. na ścianie zachodniej nawy północnej w tym samym kościele (na taką samą technikę wykonania zwrócili uwagę Żankowski i Owsiany, „Krużganek północny,” 27) oraz znacznie wcześniejsze malowidła patronalne na ścianie wschodniej prezbiterium kościoła Świętojańskiego.

10 Żankowski i Owsiany, „Krużganek północny,” 27. Zasięg późniejszych pobiał dobrze dokumentuje fotografia we fluorescencji wzbudzanej UV, zob. il. 6: b.

11 Żankowski i Owsiany, „Krużganek północny,” 21.

12 Zwrócili na to uwagę Żankowski i Owsiany, „Krużganek północny,” 27. Obecność wcześniejszej warstwy czytelna jest nieuzbrojonym okiem tuż przy narożniku ścian, w połowie wysokości malowidła. 
fazowość nie została dostrzeżona w literaturze, choć jest ważnym dokumentem aktualizowania wystroju krużganka. Stan zachowania dzieła jest bardzo niejednorodny, plamy barwne i linie (w tym kontury rysunku i wykończenia) przenikają się wzajemnie, w niektórych partiach czytelna jest - jak się wydaje - jedynie podmalówka z pierwszej warstwy z resztkami przemalowania, w innych - bardziej jednolite plamy barwne z pozostałościami podrysowania itd. Precyzyjne określenie wzajemnej relacji poszczególnych fragmentów nie jest zatem możliwe bez instrumentalnego przebadania stratygrafii tynków i warstw malarskich co najmniej w kilku miejscach, co byłoby zbyt daleko idącą ingerencją w strukturę zabytku, niewskazaną wobec stanu jego zachowania. Obserwacja powierzchni dzieła w świetle widzialnym, wspomagana przez techniki nieniszczące, pozwala jednak na wysunięcie kilku wniosków, przynoszących wiedzę o przekształceniach w obrębie malowidła.

Pierwotna kompozycja, ujęta w płaską ugrową bordiurę obwiedzioną czerwonym konturem, ograniczała się najpewniej do czterech figur - Ukrzyżowanego w asyście Marii i św. Jana Ewangelisty oraz niezidentyfikowanego świętego adoranta u stóp krzyża. Była pomyślana statycznie i oszczędnie, z pozostawieniem dużych połaci pustego tła. Neutralne tło kompozycji wypełnione zostało ciemną czerwienią (na bazie czerwieni żelazowej). Z obecnego rozmieszczenia elementów kompozycji można wnioskować, że na wysokim krzyżu typu immisa zawieszona była (drobniejsza niż obecnie) postać Zbawiciela ${ }^{13}$. Słabo poruszone, statyczne figury asystentów, ujęte frontalnie, z twarzami zwróconymi nieznacznie w stronę krzyża, miały dość przysadziste proporcje i przewyższały wielkością figurę Zbawiciela. Ich duże głowy okolone były nimbami kreślonymi z cyrkla ${ }^{14}$ i okonturowanymi bielą; wyraźnie czytelny jest pierwotny zarys głowy św. Jana, o krągłej twarzy i jasnych falujących włosach. Wydaje się, że sylwetka Marii, okryta wraz z głową błękitnym, otwartym płaszczem, którego poły zawinięte są wokół łokci (dukt fałd w dolnej partii figury nie zachował się), należy w całości do tej pierwotnej kompozycji. Postać św. Jana, odzianego w czerwony płaszcz i bladozieloną tunikę, zachowała częściowo przemalowanie z kolejnej fazy. U stóp Chrystusa, na prawo od krzyża, znajdowała się jeszcze jedna postać, nieczytelna nieuzbrojonym okiem, rozpoznawalna jedynie dzięki zarysowi nimbu na białej podmalówce oraz konturom

13 Pozostałości plam barwnych i konturu sugerują, że tors Zbawiciela był węższy; niewykluczone, że nogi ułożone były w układzie „schodkowym” (z ugiętymi kolanami), na co wskazuje gest lewej ręki Marii, nachodzącej obecnie na stopy Chrystusa.

14 Zachował się czytelny wgłębny ślad z lewej strony nimbu św. Jana. 
widocznym w bliskiej IR oraz fluorescencji wzbudzanej UV (il. 8: a, b). Postać ta trzymała na wyciągniętych rękach dość dużych rozmiarów kielich o smukłym trzonie $^{15}$. Trudno orzec, czy za oryginalne można uznać czytelne w świetle skośnym, wydrapane kontury owych rąk i pozostałość po rysach twarzy (il. 9).

Faza muru, na którą wprowadzono malowidło, powstała w konsekwencji włączenia całej pierwotnej struktury pierwszego przęsła krużganka do nowej budowli z XIV wieku, która zintegrowała je z przyziemiem nawy północnej. Zmiany w architekturze tego fragmentu były efektem przebudowy łącznika i klatki schodowej po stronie wschodniej oraz pogrubienia odcinków muru północnego w obrębie półfilarów międzynawowych, niosących ciężar empory nawy północnej i sklepień. Przebudowę tę osadzano dotąd w trzeciej ćwierci XIV wieku' ${ }^{16}$; w świetle obecnie prowadzonych badań można ją przesunąć wstecz, do pierwszej ćwierci stulecia ${ }^{17}$. Daje to możliwość datowania pierwszego malowidła dość wcześnie (na pierwszą połowę XIV wieku), ale wobec jego stanu zachowania dokładna metryka jest trudna do ustalenia. Można się domyślać, że w swym ogólnym oddziaływaniu ta pierwotnie raczej surowa kompozycja (z dużymi połaciami pustego tła) przypominała malowane retabulum z Ukrzyżowaniem zachowane w kościele św. Jana Chrzciciela i św. Jana Ewangelisty w Toruniu na drugim od zachodu filarze po stronie północnej (il. 10) ${ }^{18}$.

15 Obecność nimbu i kielicha wyklucza zakonnika (postaci zakonników pojawiają się w tym miejscu w ikonografii Ukrzyżowania u mendykantów, zwłaszcza u dominikanów). Być może, biorąc pod uwagę nimb wokół głowy i franciszkańską tradycję ikonograficzną, mógł to być św. Franciszek lub - co bardziej prawdopodobne - Eklezja zbierająca krew Chrystusa do kielicha (jak na kwaterze Quinitas na Poliptyku Toruńskim); niestety żadnej z tych hipotez nie da się potwierdzić.

16 Zob. m.in. Zbigniew Nawrocki, „Pofranciszkański kościół NMP w Toruniu. Próba rekonstrukcji dziejów budowy," Zeszyty Naukowe Uniwersytetu Mikołaja Kopernika w Toruniu. Zabytkoznawstwo i Konserwatorstwo 2 (1966): 63-80; Zbigniew Nawrocki, „Kościół Mariacki w Toruniu - budowa i przebudowy w świetle odkryć w ostatnim ćwierćwieczu," w Dzieje i skarby kościoła Mariackiego w Toruniu. Materiały z konferencji przygotowanej przez Toruński Oddział SHS przy współpracy Instytutu Zabytkoznawstwa i Konserwatorstwa UMK, red. Katarzyna Kluczwajd (Toruń: TNOiK, 2005), 19-53; por. Teresa Mroczko, „Programy architektoniczne zakonów żebrzących na ziemi chełmińskiej w XIII i XIV wieku,” w Sztuka i ideologia XIV wieku w Polsce. Materiały sympozjum Komitetu Nauk o Sztuce PAN, Warszawa, 29 i 30 listopada 1973, red. Piotr Skubiszewski (Warszawa: PWN, 1975), 318-320; Teresa Mroczko, Architektura gotycka na ziemi chełmińskiej (Warszawa: PWN, 1980), 130-138, 296-307.

17 Wyniki badań w druku; upublicznione na międzynarodowej konferencji naukowej: Monika Jakubek-Raczkowska i Juliusz Raczkowski, „Dawny kościół Franciszkanów w Toruniu. Między regułą a tradycją miejsca / Ancienne église des Cordelières de Toruń d'aprés des recherches récentes. Entre la régle et les besoins du lieu” (referat na konferencji PTPN „Klasztor i kolegiata w średniowiecznej Europie”, Poznań, 9-12 grudnia 2020 r.).

18 Malowidło o wym. $115 \times 80 \mathrm{~cm}$, odsłonięte podczas prac konserwatorskich przy nastawie ołtarzowej w 2008 r., po ich zakończeniu na powrót przesłonięte nowożytną nastawą; opubli- 
W drugiej fazie obrazowi starano się nadać większą przestrzenność, kompozycję zagęszczono, a proporcje postaci wydłużono, pozostawiając purpurowe neutralne tło. Bordiurę obrazu opracowano bardziej malarsko - rozbudowano ją od wewnątrz o nieco węższy pas ciemniejszego koloru, okonturowany czernią. Podobne działanie w stronę „perspektywy” widoczne jest na belkach krzyża, które zostały wzdłużnie podzielone i zróżnicowane kolorystycznie (ugier w partii „światła” i brąz w partii „cienia”). Do tej fazy należy czytelna obecnie sylweta Chrystusa (jak już wspomniano, partia głowy, pierwotnego nimbu i górna część ramion zostały przypadkowo skute, obecny ich wygląd jest wynikiem uzupełnienia konserwatorskiego). Ciało Zbawiciela zawieszone jest pionowo w osi krzyża na nieznacznie ugiętych, szeroko rozrzuconych ramionach; biodra są lekko skręcone w prawo, nogi złączone $^{19}$. Tors został poszerzony (częściowo zatarte dziś uzupełnienie po lewej stronie położono na czerwonym tle z poprzedniej fazy, we fluorescencji UV widoczny jest kształt rany w boku), a cała jego sylweta - powiększona i wydłużona. Proporcje postaci są bardzo smukłe, niemal rachityczne, wystylizowane za pomocą płynnej linii, którą uwydatniono stawy, krągłość bioder i zarys łydek. Partia perizonium (il. 11: a) zachowała się bardzo słabo, układ draperii nie jest w pełni czytelny w świetle widzialnym, uwydatnia go dopiero fluorescencja UV, ujawniająca cienki rysunek fałd (il. 11: b). Na podstawie fotografii w światłach technicznych można jedynie stwierdzić, że chusta zawieszona nisko na biodrach szczelnie owija uda Zbawiciela, jej lewa poła jest poprowadzona ukośnie w górę (odsłania kolano) i marszczy się promieniście, z prawego biodra opada zaś feston sięgający poniżej prawego kolana, czytelny jedynie w ogólnym zarysie. Z ran Chrystusa wypływa krew, zaznaczona szerokimi pociągnięciami pędzla jako smugi cieknące do kielichów - z prawej ręki, wzdłuż całego przedramienia, krople krwi skapują pionowo, z rany w boku tryska potrójny strumień o łukowatym przebiegu (il. 12: a, b) - ślady tych detali są w zasadzie nierozpoznawalne w świetle widzialnym. Z sylwety Marii Bolesnej z tej fazy zachowały się jedynie szczątki położonego na du-

kowane wkrótce potem, zob. Juliusz Raczkowski, „Najnowsze odkrycia w zakresie gotyckiego malarstwa ściennego w Prusach i ich znaczenie dla badań nad sztuką regionu," w Homo Creator et Receptor Artium. Księga pamiątkowa Księdzu Profesorowi Stanisławowi Kobielusowi ofiarowana, red. Małgorzata Wrześniak (Warszawa: UKSW, 2010), 99-100.

19 Na malowidle nie zachowały się stopy Ukrzyżowanego, nie można zatem stwierdzić, w jaki sposób ukazano ich przebicie. 
żych partiach azurytu ${ }^{20}$ i zarys lewego ramienia (?) na czerwonym tle (por. il. 6). Czytelne są natomiast przekształcenia postaci św. Jana, której nadano zdecydowanie silniejszą ekspresję, zmieniając układ głowy - „nowa” twarz o wyrazistych rysach została ustawiona lewym profilem do widza i skierowana ku Chrystusowi (il. 13: a-b). Gestykulacja postaci jest dynamiczna, święty prawą rękę unosi przed sobą, ostentacyjnie wskazując na Zbawiciela (układ dłoni nie jest czytelny), w lewej ręce, wysuniętej nienaturalnie w bok, trzyma zamkniętą księgę, której blok został częściowo wmalowany w wewnętrzną bordiurę obrazu. Zestawienie uniesionej w górę twarzy i skierowanej ku górze ręki sprawia, że postać zyskuje na swobodzie i ekspresji.

Bardzo ciekawe wyniki przynosi obserwacja dolnej części kompozycji, wskazująca, że zmieniono również szczegóły postaci adoranta u stóp krzyża. Zwłaszcza w widoku w IR uczytelnia się - gołym okiem słabo zauważalna - główka kobieca (św. Maria Magdalena?), zachowana zaskakująco dobrze (il. 14: a-b). Została ona wmalowana lekko na prawo od widniejącego w spodniej warstwie nimbu i ma bardzo drobne proporcje. Jej twarz jest uniesiona ku Chrystusowi, ujęta w trzech czwartych i ma idealizowane, młodzieńcze rysy, o ogólnych cechach stylowych malarstwa gotyckiego końca XIV - pierwszej połowy XV wieku. Modelowana jest dość miękko, z użyciem brunatnego konturu; jej relację stylową względem pozostałych partii malowidła trudno precyzyjnie ocenić.

Wydaje się prawdopodobne, że dopiero na drugim etapie przekształceń dodano cztery smukłe figury aniołów w błękitnych tunikach, unoszące się po bokach krzyża - po dwie z każdej strony, o wąskich, dynamicznych skrzydłach; motyw znany z malarstwa Trecenta ${ }^{21}$ oraz ze sztuki czeskiej trzeciej ćwierci XIV wieku ${ }^{22}$. Anioły ukazane w górnym rzędzie zbierają do kielichów mszalnych krew cieknącą z dłoni Chrystusa; anioł unoszący się nad Marią

20 Pomiary przenośnym spektrometrem rentgenowskim XRF (J. Raczkowski, 2020) wykazały dominację miedzi (82\%), co wskazuje na zastosowanie popularnego azurytu.

${ }^{21}$ Redakcja Ukrzyżowania z aniołami występowała w malarstwie Trecenta już od pocz. XIV w. - także w kręgu franciszkańskim (gdzie u stóp krzyża umieszczano postaci św. Franciszka i św. Klary, np. na obrazach Bernarda Daddiego, Giovanniego da Milana).

22 Por. np. tablica Ukrzyżowanie z Vyšsego Brodu (galeria w opactwie cysterskim w Vyšsim Brodzie). Na terenie państwa zakonnego najbliższą analogię stanowi częściowo zrekonstruowane w 1916 r. malowidło w Izbie Kuchmistrza na Zamku Średnim w Malborku, dat. na ok. 1360 r., zob. Monika Jakubek-Raczkowska i Juliusz Raczkowski, „Średniowieczny wystrój zespołu Wielkiego Refektarza na Zamku Średnim w Malborku," w Wielki Refektarz na Zamku Średnim w Malborku. Dzieje - wystrój - konserwacja, red. Janusz Trupinda (Malbork: Muzeum Zamkowe, 2010), 72-80. 
zbiera krew spływającą z rany z boku; atrybut anioła ukazanego naprzeciwko (zapewne trybularz) nie zachował się. Kielichy mają smukłe wysokie trzony i duże hemisferyczne czary. Poza aniołem zbierającym krew z rany w boku, pozostałe anielskie postaci ujęte są tylko do połowy - wyłaniają się spoza ram pola obrazowego. Figury te zostały namalowane na czerwonym tle, bez dodatkowych podmalowań, ich stroje i skrzydła obwiedziono czarnym konturem (il. 15: a-b). Linearnie potraktowane były pióra skrzydeł, zachowane tylko u anioła w lewym górnym rogu obrazu, który jako jedyny ma też czytelną kolorystykę jasnobłękitnej szaty i skrzydeł o nieco zielonkawym, turkusowym tonie ${ }^{23}$. Błękit szat fragmentarycznie przetrwał również $\mathrm{u}$ anioła ukazanego w całej postaci, przy czym warstwa malarska w dolnej partii jego tuniki uległa przetarciu (tylko kontury oddzielają tę sylwetę od czerwonego tła).

Omówioną tu fazę przekształceń można datować na przełom XIV i XV wieku. Wskazuje na to typ ikonograficzny (wyprężona pionowo postać Ukrzyżowanego, układ perizonium) oraz ogólne cechy stylu (proporcje sylwety Chrystusa, jego smukła budowa anatomiczna, kształt skrzydeł aniołów). Najbardziej charakterystycznym motywem, który pozwala osadzić tę kompozycję w modnym w Toruniu w tym czasie modusie czeskim, jest profil św. Jana Ewangelisty, o dużym nosie z głęboką nasadą i o lekko cofniętym czole. Tę charakterystyczną stylizację fizjonomii, typową dla malarstwa czeskiego i znaną choćby z malowideł krużganka praskiego klasztoru Emaus i z czeskiego miniatorstwa (il. 16), znajdujemy w malowidle z Koronacją Marii w pierwszym od wschodu przęśle nawy południowej kościoła NMP w Toruniu (il. 17), które datować można na ten sam okres. Analogii dla układu kompozycyjnego i typów figur aniołów dostarcza z kolei nieco wcześniejsze (ostatnia ćwierć XIV w.) malowidło z Wniebowzięciem św. Marii Magdaleny na północnej ścianie międzynawowej w tym kościele. Wobec słabego stanu zachowania Ukrzyżowania trudno snuć dywagacje o jego proweniencji warsztatowej, niemniej jednak te wzajemne analogie, jak i niezauważona jak dotąd zależność od czeskich pierwowzorów, zasługują na odnotowanie.

Podsumowując analizę strukturalną można stwierdzić, że omawiany obraz z Ukrzyżowaniem został namalowany w bliżej nieokreślonym momencie po przebudowie kościoła w pierwszej połowie XIV wieku, kiedy dawny krużganek stał się przyziemiem nawy północnej. Malowidło „zaktualizowano”

23 Pomiary przenośnym spektrometrem rentgenowskim XRF (J. Raczkowski, 2020) wykazały dominację miedzi (Cu 78\%), co wskazuje na zastosowanie zieleni miedziowej zmieszanej $\mathrm{z}$ bielą ołowiową $(\mathrm{Pb}$ w pomiarze $18 \%)$. 
pod koniec XIV stulecia, nadając mu nowe cechy stylowe oraz wzbogacając ikonografię i wymowę symboliczną. Nastąpiło to zapewne w ramach innych prac przy wystroju wnętrza, prowadzonych ówcześnie w kościele Mariackim ${ }^{24}$ (wydaje się, że było to w trakcie finalnej kampanii budowlanej, w wyniku której kościół uzyskał całościowe zasklepienie ${ }^{25}$ ).

Wobec braku źródeł archiwalnych dotyczących praktyk religijnych u toruńskich franciszkanów trudno określić pierwotną funkcję przedstawienia. Jest to zadanie tym bardziej problematyczne, że stosunkowo niewiele wiadomo o uzusie średniowiecznych krużganków (claustrum) i podziale funkcjonalnym ich przestrzeni ${ }^{26}$; kwestie te są mało poświadczone źródłowo także dla zakonu franciszkanów ${ }^{27}$. Podstawową funkcją krużganków było skomunikowanie kościoła i klasztoru. Wiadomo, że były one również miejscem pochówku brackiego ${ }^{28}$ i liturgii, zwłaszcza w Wielkim Tygodniu ${ }^{29}$ (u franciszkanów in claustro zapalano ogień podczas obchodów Wielkiej Soboty ${ }^{30}$ ); w ich przestrzeni odbywały się też procesje $\mathrm{e}^{31}$. Ponadto były strefą prywatnej praktyki

${ }^{24}$ W 4. ćw. XIV w. powstała Koronacja NMP oraz malowidła z archaniołami w pierwszym od wschodu przęśle nawy południowej, a także Modlitwa w Ogrójcu i Niesienie krzyża w przęśle zachodnim. Na koniec XIV w. datować można pozostałości rzeźb z wyposażenia - Chrystusa z grupy Koronacji Marii (obecnie w Muzeum Diecezjalnym w Pelplinie) oraz Chrystusa w Grobie (depozyt w Muzeum Okręgowym w Toruniu), a także młodsze tablice Poliptyku Toruńskiego. Wszystko to wskazuje na intensywne działania przy modernizacji kościoła na przełomie XIV i XV w.

25 W literaturze (por. przyp. 17) zgodnie przyjmowano, że prace budowlane i zasklepienie korpusu i prezbiterium zostały zakończone na przełomie XIV i XV w.; nie wnikając w szczegóły chronologii budowy, można uznać to datowanie za słuszne: malowidła na wysklepkach sklepiennych w prezbiterium noszą cechy stylu międzynarodowego.

26 Zob. Paul Meyvaert, „The Medieval Monastic Claustrum,” Gesta 12, Nr. 1-2 (1973): 53-59; Regine Abegg, „Funktion des Kreuzgangs im Mittelalter: Liturgie und Alltag,” Kunst + Architektur in der Schweiz 48 (1997): 6-24.

27 Istniejące źródła i pośrednie dane zestawiła w krótkiej analizie Leonie Silberer, Domus fratrum minorum. Klosterbaukunst der konventualer Franziskaner vom 13. Jahrhundert bis zur Reformation (Studien zur internationalen Architektur und Kunstgeschichte 141) (Petersberg: Imhof-Verlag, 2016), 156-168.

28 Martin Illi, „Der Kreuzgang als Bestattungsort,” Kunst + Architektur in der Schweiz 48 (1997): 47-55. U toruńskich franciszkanów jednoprzestrzenna krypta pochówkowa, którą można interpretować jako miejsce wspólnego pochówku braci zakonnych, usytuowana jest na całej długości nawy północnej (czyli dawnego południowego skrzydła krużganka).

29 Abegg, „Funktion des Kreuzgangs,” o obrzędach Wielkiej Soboty: 12-13, o Mandatum: 17.

30 Silberer, Domus fratrum minorum, 156.

31 Abegg, „Funktion des Kreuzgangs,” 7-11, na podstawie badań źródłowych dla różnych ośrodków religijnych (klasztornych i katedralnych) w Europie Zachodniej wymienia organizowane w krużgankach: procesje niedzielne i uroczyste, procesje na Boże Narodzenie i Niedzielę Palmową, procesje błagalne oraz żałobne (związane z pochówkiem i memorią). O pro- 
religijnej w klasztorach ${ }^{32}$ i służyły różnym celom pragmatycznym ${ }^{33}$, które jednak nie są poświadczone w źródłach dla minorytów ${ }^{34}$. Dostępność franciszkańskich krużganków dla wiernych świeckich ${ }^{35}$ (obejmująca często skrzydło południowe oraz fundowane przez laikat kaplice) nie jest w pełni przebadana. W późnym średniowieczu przestrzenie te najczęściej zasklepiano, a na ściany wprowadzano dekorację malarską, nadając im reprezentacyjny charakter ${ }^{36}$.

Niezwykle skąpe źródła archiwalne dotyczące kościoła NMP w Toruniu nie przynoszą żadnych informacji o przestrzeni krużganka, który zgodnie ze zwyczajem musiał zachowywać - przynajmniej do pewnego stopnia - status klauzurowy. Jego południowe skrzydło, architektonicznie włączone w strukturę korpusu nawowego jako przyziemie nawy północnej, musiało jednak funkcjonować z uwzględnieniem zarówno potrzeb konwentu, jak i praktyki religijnej świeckich. Na dostęp laikatu wskazuje skomunikowanie tego wnętrza z nawą główną, wydzielenie w nim osobnej kaplicy - uznawanej w literaturze za kaplicę Grobu św., a także powiązanie zakrystii z memorią świeckich w czasie czternastowiecznej przebudowy ${ }^{37}$. Nie rozstrzyga to oczywiście o funkcji ani o kontekście fundacyjnym malowidła. Choć w kościele zachowały się przykłady malowideł związanych z donacjami świeckich, są one skoncentrowane w przestrzeni korpusu nawowego (ecclesia laicorum) ${ }^{38}$; dla nawy północnej należy raczej zakładać zamierzony uzus zakonny. Dość niskie usytuowanie dzieła (około $110 \mathrm{~cm}$ od poziomu pierwszej posadzki) pozwala sądzić, że nie było ono raczej powiązane z ołtarzem. Jest ponadto umieszczone niezgodnie z osią liturgiczną kościoła (lico fazy muru skierowane jest ku pół-

cesjach i ich przebiegu u franciszkanów wiadomo niewiele; ze skąpych źródeł miejscowych wynika, że procesje w krużgankach organizowano m.in. na uroczystość Wszystkich Świętych oraz w Boże Ciało, zob. Silberer, Domus fratrum minorum, 157.

32 Przede wszystkim lektury, modlitwy i milczącej medytacji (silentium), zob. Meyvaert, "The Medieval Monastic Claustrum,” 54-55; Abegg, „Funktion des Kreuzgangs,” 15-16.

33 Np. pranie, czyszczenie obuwia, strzyżenie i golenie, obmywanie stóp, zob. Meyvaert, „The Medieval Monastic Claustrum,” 55; Abegg, „Funktion des Kreuzgangs,” 17.

34 Silberer, Domus fratrum minorum, 157.

35 O problemie dostępności krużganków zob. ogólnie Abegg, „Funktion des Kreuzgangs,” 14-15.

36 Por. omówienie zachowanych wnętrz i wystrojów: Silberer, Domus fratrum minorum, 157-168.

37 Zakrystia, która w budowli XIII-wiecznej musiała mieć charakter klauzurowy i skomunikowana była wyłącznie ze strefą sacrosanctum, w budowli XIV-wiecznej została powiększona od wschodu, zasklepiona i otwarta nowym portalem do nawy północnej. Zachowany pod posadzką pochówek oraz wprowadzenie zworników z herbami i wizerunkami świeckich mężczyzny i kobiety - wskazują na nadanie jej nowych funkcji w ramach memorii laikatu.

38 Są to: słabo zachowane przedstawienie wotywne (?) ze św. Barbarą (?) i adorantami na ścianie zachodniej nawy południowej oraz malowidło ze statkiem rzecznym na ścianie północnej w pierwszym od wschodu przęśle nawy głównej. 
nocnemu wschodowi). Być może ze względu na pasyjną ikonografię odgrywało jakąśs rolę w liturgii procesyjnej lub stacyjnej, np. w okresie Wielkiego Postu i Wielkiej Nocy lub w ramach obrzędu ignis paschalis; jego stała dostępność zapewniała mu też samorzutne funkcje dewocyjne ${ }^{39}$. Warto zwrócić uwagę, że motyw zbierania krwi Chrystusa do kielichów, a zwłaszcza wyeksponowanie postaci anioła zbierającego krew z rany w boku, nadały kompozycji zdecydowanie eucharystyczny wymiar, co mogło się łączyć z kultem Krwi Pańskiej bądź Pięciu Ran, obecnym w mistyce franciszkańskiej i promowanym przez mendykantów. Nie można zatem wykluczyć, że obraz pełnił funkcje dewocyjne podczas prywatnej medytacji braci lub spontanicznej modlitwy świeckich.

Niezależnie od pierwotnego przeznaczenia, którego wobec braku archiwaliów nie można obecnie ustalić, obecność przedstawienia w tym właśnie miejscu nie mogła być przypadkowa. Wschodnie przęsło przyziemia nawy północnej - jak się wydaje, jedyny fragment trzynastowiecznej struktury krużganka zachowany w całości - pełniło ważną funkcję komunikacyjną, z którą mogły się wiązać elementy jego wystroju. Przez łukowatą arkadę łączyło się ze wschodnim skrzydłem krużganka, przez ostrołuczny portal z nawą główną; stąd prowadziło też wejście do zakrystii, wykute prawdopodobnie podczas czternastowiecznej przebudowy. Być może - jak proponowali swego czasu Ryszard Żankowski i Krzysztof Owsiany - sens ideowy i lokalizacja obrazu z Ukrzyżowaniem związane były z funkcją portalu, przez który celebrans mógł wychodzić przed ołtarz (była to od XIV wieku nowa droga z zakrystii do prezbiterium $)^{40}$. W tej partii kościoła mieściła się również najstarsza część krypty pochówkowej braci - wejście do niej znajduje się do dziś w drugim przęśle od wschodu, nad którym założono dekoracyjne sklepienie ${ }^{41}$.

Istotną rolę tej „łącznikowej” części klasztoru podkreślono w późnym średniowieczu ornamentalną polichromią - na sklepienie wprowadzono gęstą

39 Stała dostępność obrazów, umożliwiająca spontaniczną praktykę religijną poza ramami liturgii, jest jednym z podstawowych wyróżników ich potencjalnej funkcji dewocyjnej, trafnie wskazanym przez Marcinkowskiego, zob. Wojciech Marcinkowski, Przedstawienie dewocyjne jako kategoria sztuki gotyckiej (Kraków: Wydawnictwo i Drukarnia „Secesja”, 1994), 48.

40 Żankowski i Owsiany, „Krużganek północny,” 25. W momencie włączenia krużganka w obręb nawy północnej przekształcono też dawny łącznik i klatkę schodową komunikującą wcześniej kościół i II kondygnację klasztoru; w efekcie konieczne było utworzenie nowego połączenia z zakrystią, która w kościele XIII-wiecznym dostępna była jedynie przez łącznik bezpośrednio z prezbiterium.

41 Żankowski i Owsiany, „Krużganek północny,” 32-33, dekoracyjny układ żeber i zworników objaśniali - za Z. Nawrockim - jako możliwy zabieg maskowania mechanizmu podnoszenia płyty zamykającej wejście. Por. też przyp. 28. 
zieloną wić roślinną. Datowanie tej dekoracji nie jest niestety oczywiste ze względu na prace restauratorskie, które zniekształciły pierwotną formę i kolorystykę wici ${ }^{42}$. W większości opracowań przyjmuje się, że powstała na przełomie XV i XVI wieku ${ }^{43}$, nie można jednak ostatecznie wykluczyć, że namalowana została nawet wcześniej (na przykład przy okazji zasklepienia kościoła około 1400 roku), tym bardziej że do innej - stylistycznie późniejszej - fazy zdobień należą polichromie z bujną roślinnością na ścianach tarczowych ${ }^{44}$, $\mathrm{z}$ miękkimi rozłożystymi formami roślinnymi i powtarzającym się motywem wazonów (il. 18) ${ }^{45}$. Ukrzyżowanie - wprowadzone do tego wnętrza jako autonomiczne przedstawienie - stało się z biegiem czasu integralną częścią większego, „narastającego” systemu polichromii, wyróżniającego przęsło wschodnie z traktu dawnego krużganka (por. il. 1). Choć słabo zachowane, mało atrakcyjne wizualnie i w literaturze pomijane, jest ono jednym z najstarszych elementów wystroju nawy północnej. Mimo szczątkowej formy, uniemożliwiającej pełne rozpoznanie artystyczne, w tym właśnie stanie: z czytelnymi przekształceniami - zachowuje nośność dokumentalną i niezbywalną wartość historyczną jako element pofranciszkańskiego dziedzictwa w Toruniu.

\section{Finansowanie}

Tekst referuje wyniki badań i prac inwentaryzacyjnych wykonanych w ramach realizacji projektu Narodowego Programu Rozwoju Humanistyki MNiSW „Inwentarz sztuki Torunia, cz. 1, Dziedzictwo sakralne, zespół staromiejski”, nr 0122/NPRH6/ H11/85/2018.

42 Żankowski i Owsiany, „Krużganek północny,” 26-27.

43 Polichromia ta została niestety bardzo silnie zniekształcona podczas prac konserwatorskich-restauratorskich prowadzonych w 1. 1970-1971, dlatego datowanie wici nie jest do końca pewne. Jej dość sucha, strzępiasta forma zdaje się typowa dla końca XV w. i zbliża te zdobienia do dekoracji znanych z kamienic mieszczańskich przy ul. Kopernika 15 i Łaziennej 22 - wszystkie zaliczane są do wspólnej fazy późnogotyckiej, zob. Monika Jakubek-Raczkowska, Juliusz Raczkowski, i Tomasz Kowalski, Średniowieczne malowidła ścienne w kamienicach mieszczańskich Starego i Nowego Miasta Torunia / Medieval Wall Paintings in Burghers' Houses of the Old and New Town of Toruń (Toruń: TNT, 2017), 72-73, il. 124-128. Nie ulega jednak kwestii, że ten system ornamentalny, oparty na pojedynczej giętkiej zielonej gałęzi z odrostami, uformował się wcześniej, ok. 1400 r. Wobec silnego zniekształcenia polichromii mariackich ten problem pozostaje na razie otwarty.

44 Odsłonięte w 1978 r. podczas praktyk wakacyjnych studentów konserwacji i restauracji dzieł sztuki z Wydziału Sztuk Pięknych UMK; prace prowadzone były pod kierunkiem Bogumiły Rouby. Żankowski i Owsiany, „Krużganek północny,” 23-26.

45 Ten system, datowany na pocz. XVI w., znajdujemy w dekoracji w Świętojańskiej farze i w kamienicach mieszczańskich w Toruniu - por. Jakubek-Raczkowska, Raczkowski, i Kowalski, Średniowieczne malowidła, 74-75. 
a

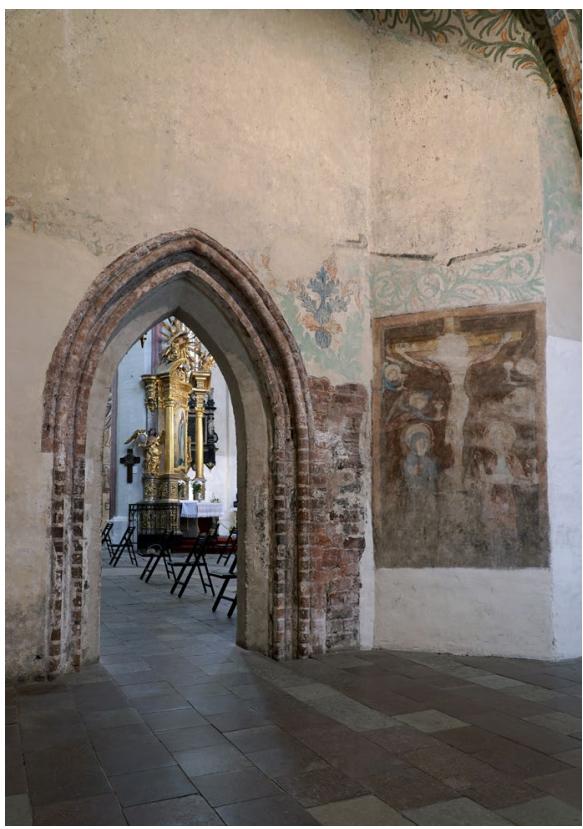

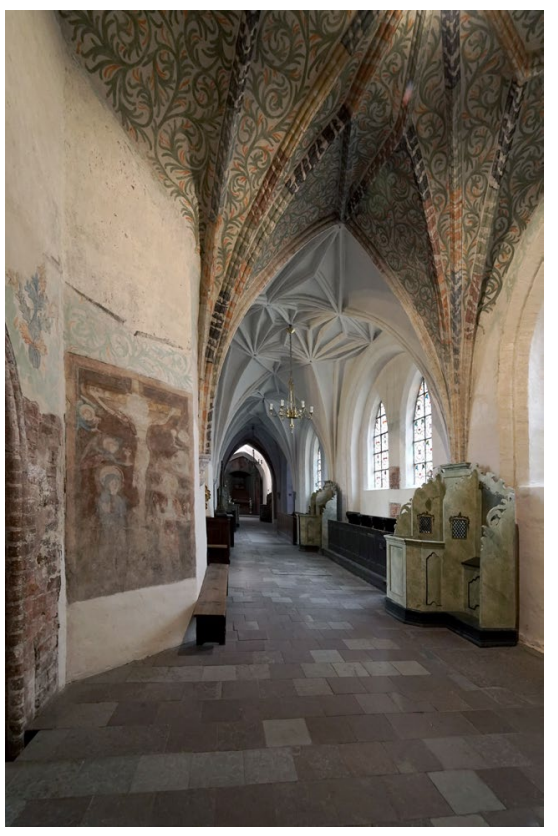

Il. 1. Toruń, kościół pw. Wniebowzięcia NMP, pierwsze przęsło od wschodu w nawie północnej (dawnym krużganku): a - widok w kierunku nawy głównej, b - widok ku zachodowi. Fot. J. Raczkowski 


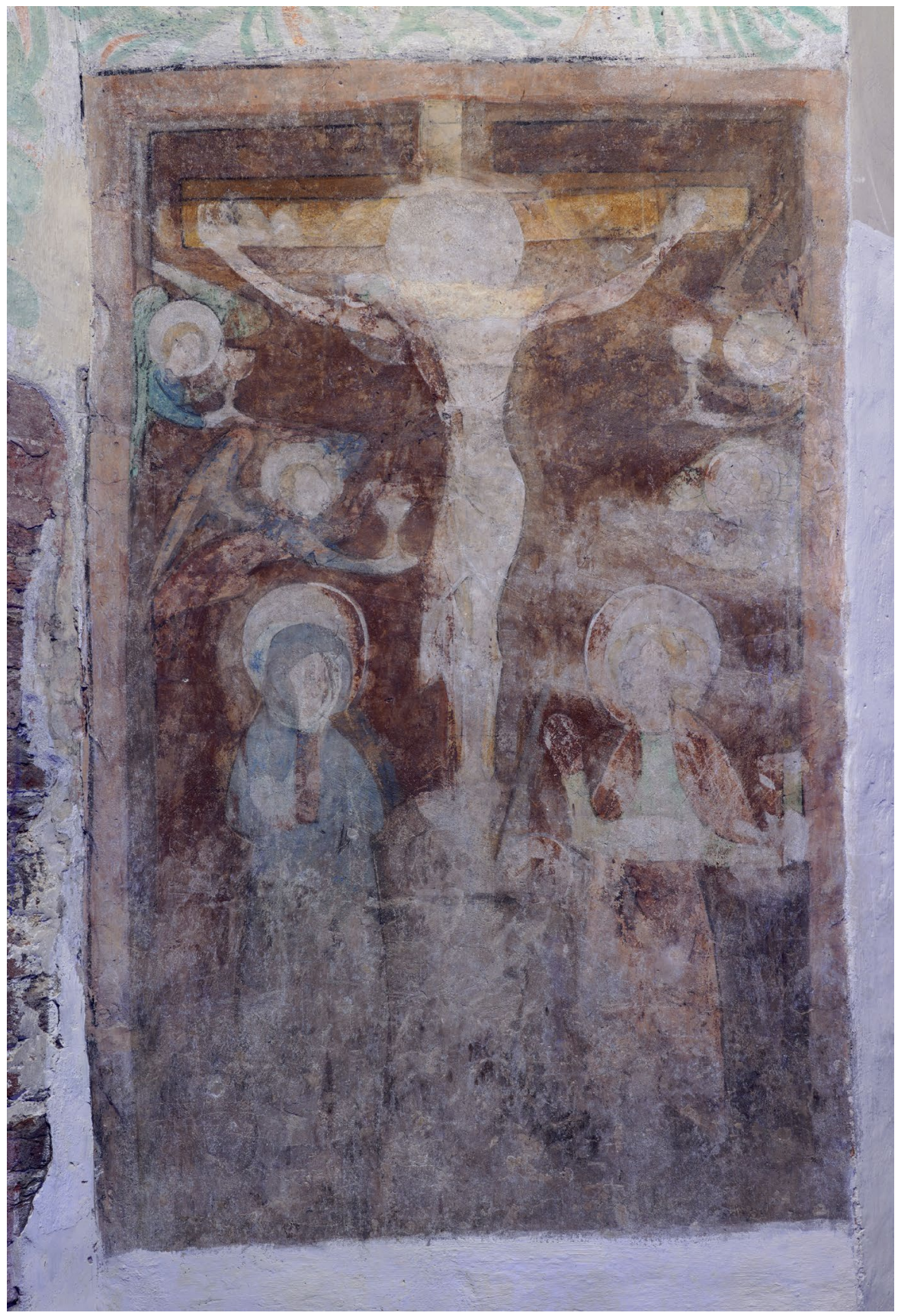

Il. 2. Toruń, kościół pw. Wniebowzięcia NMP, malowidło z Ukrzyżowaniem w nawie północnej, widok ogólny. Fot. J. Raczkowski 


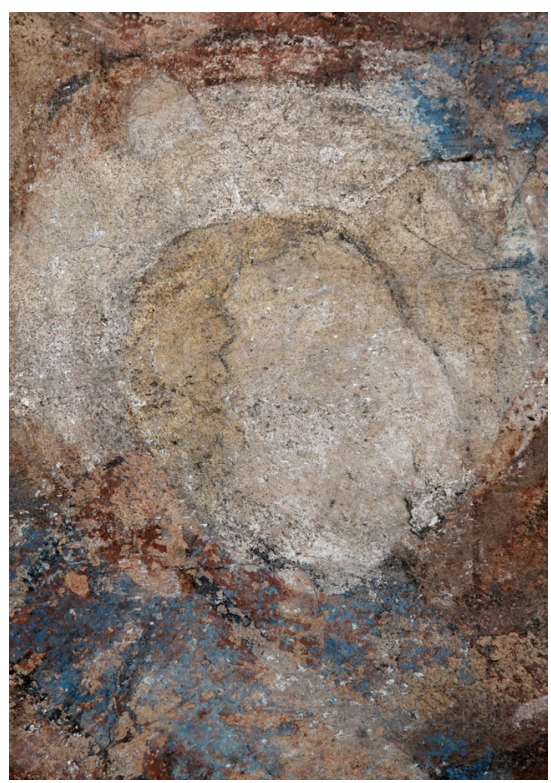

Il. 3. Toruń, kościół pw. Wniebowzięcia NMP, malowidło z Ukrzyżowaniem w nawie północnej, fragment - głowa anioła. Widoczne zniszczenia warstw malarskich. Fot. J. Raczkowski

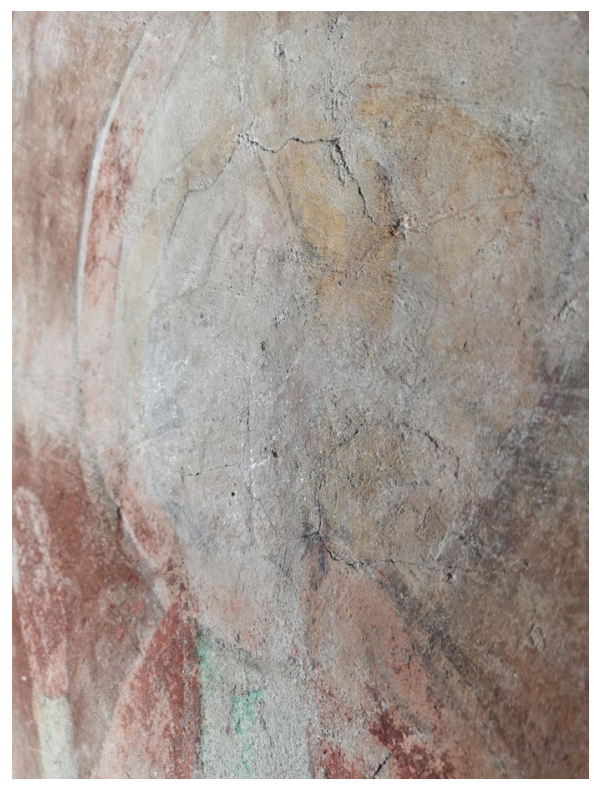

Il. 4. Toruń, kościół pw. Wniebowzięcia NMP, malowidło z Ukrzyżowaniem $\mathrm{w}$ nawie północnej, fragment - głowa św. Jana w świetle skośnym. Widoczne zniszczenia warstw malarskich i spękania powierzchni tynku. Fot. J. Raczkowski

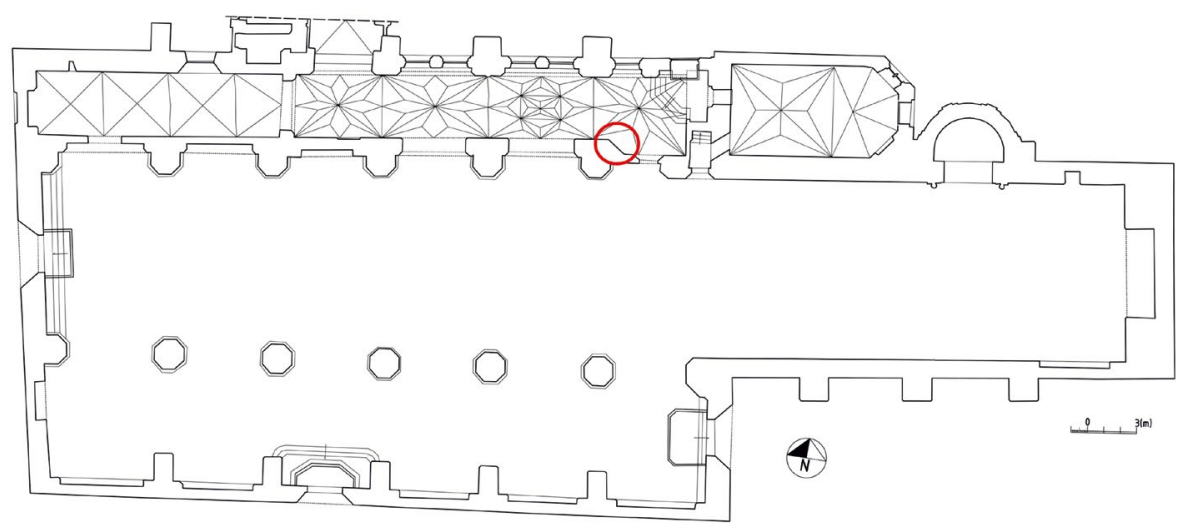

Il. 5. Toruń, kościół pw. Wniebowzięcia NMP, plan z oznaczeniem lokalizacji malowidła. Rys. T. Kowalski 


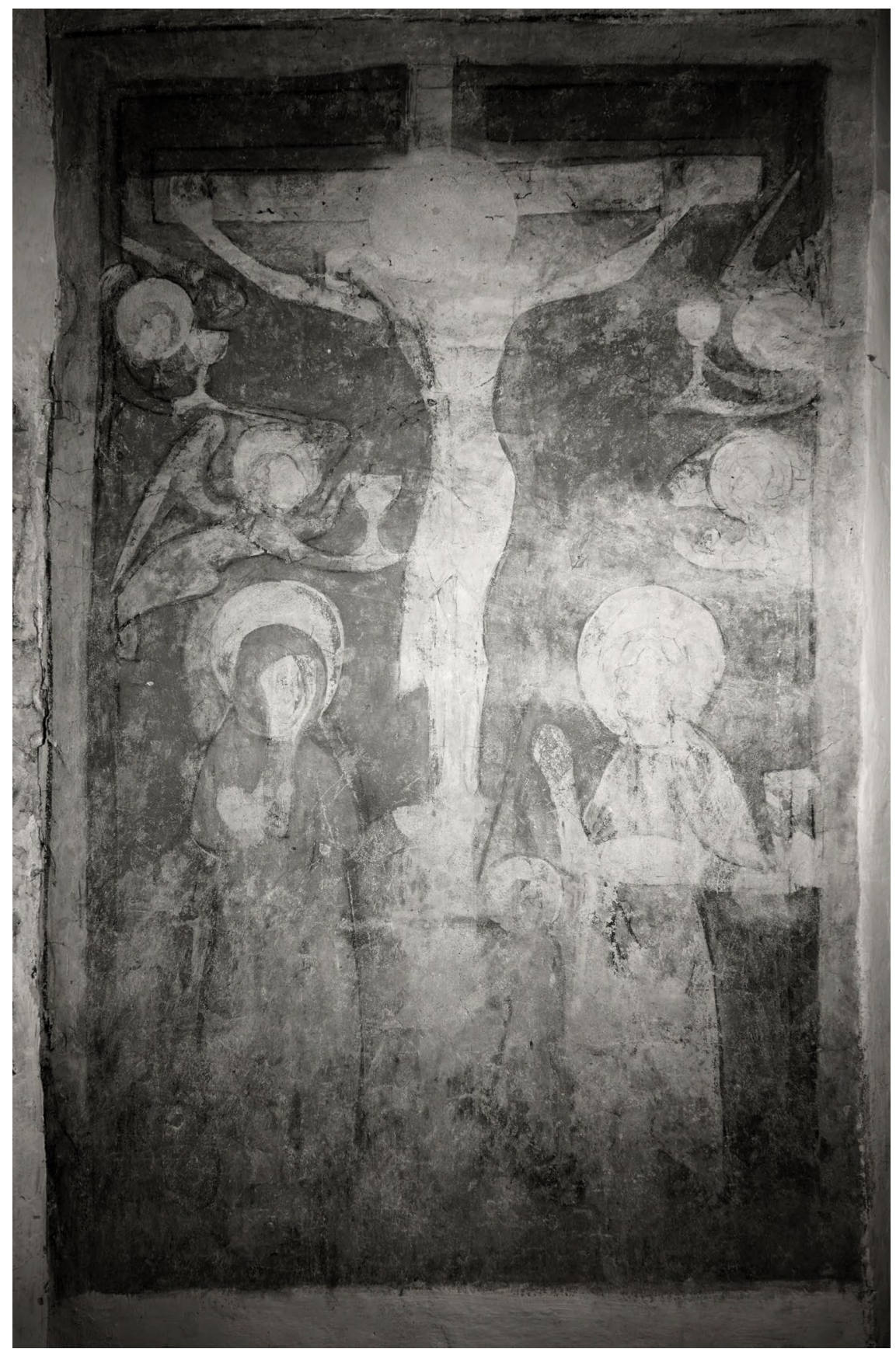

Il. 6a. Toruń, kościół pw. Wniebowzięcia NMP, malowidło z Ukrzyżowaniem w nawie północnej, widok ogólny w reflektografii IR. Fot. J. Raczkowski 


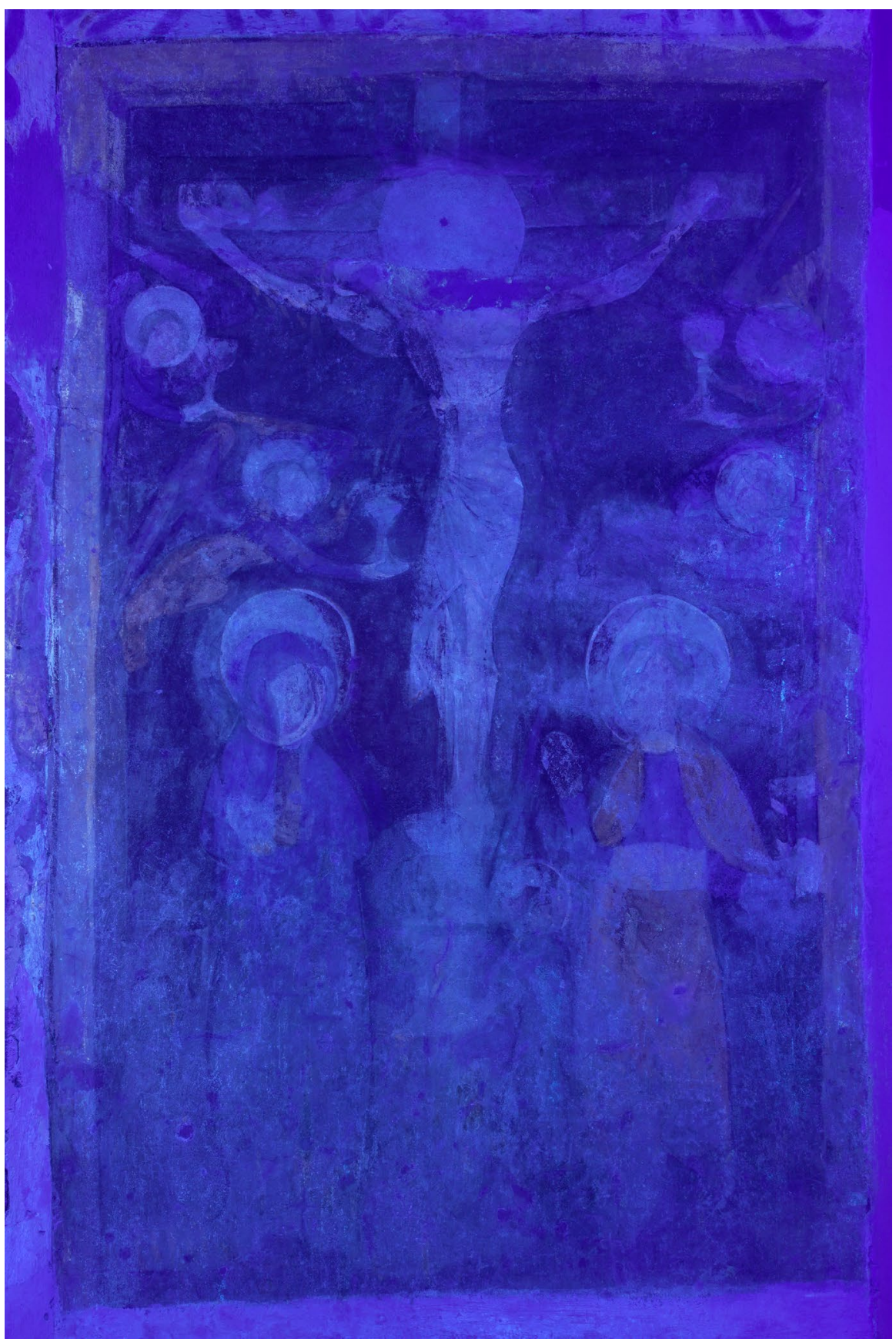

Il. 6b. Toruń, kościół pw. Wniebowzięcia NMP, malowidło z Ukrzyżowaniem w nawie północnej, widok ogólny we fluorescencji wzbudzanej UV. Fot. J. Raczkowski 


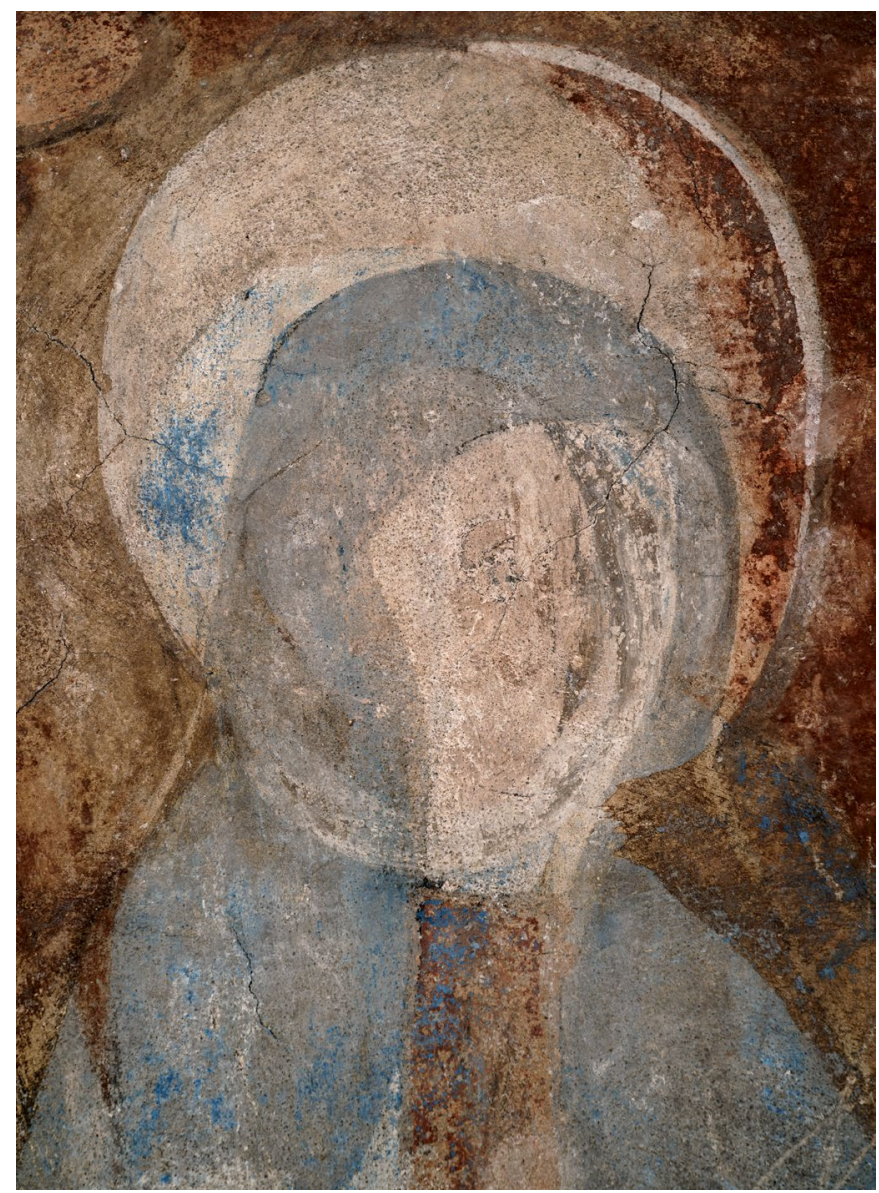

Il. 7. Toruń, kościół pw. Wniebowzięcia NMP, malowidło z Ukrzyżowaniem w nawie północnej, fragment - głowa Marii Bolesnej. Widoczne przetarcia i spudrowania warstw malarskich (z silnie wytartymi partiami błękitu leżącymi na wcześniejszej kompozycji). Fot. J. Raczkowski 
a

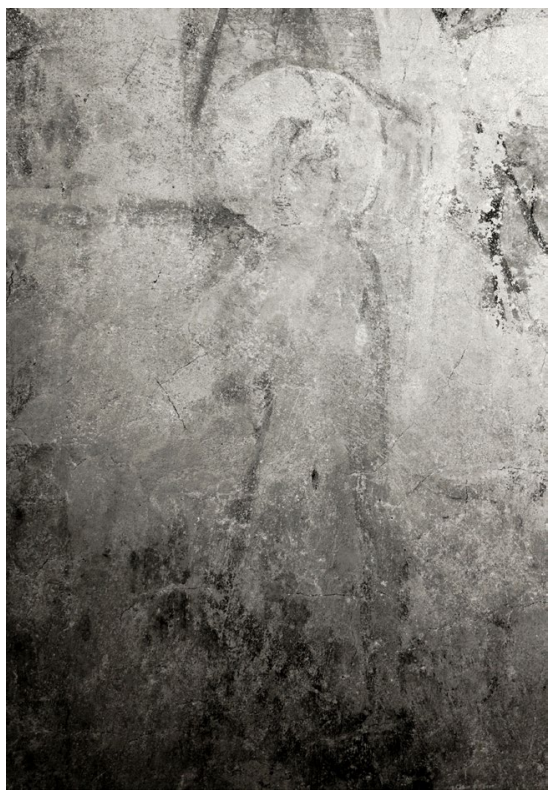

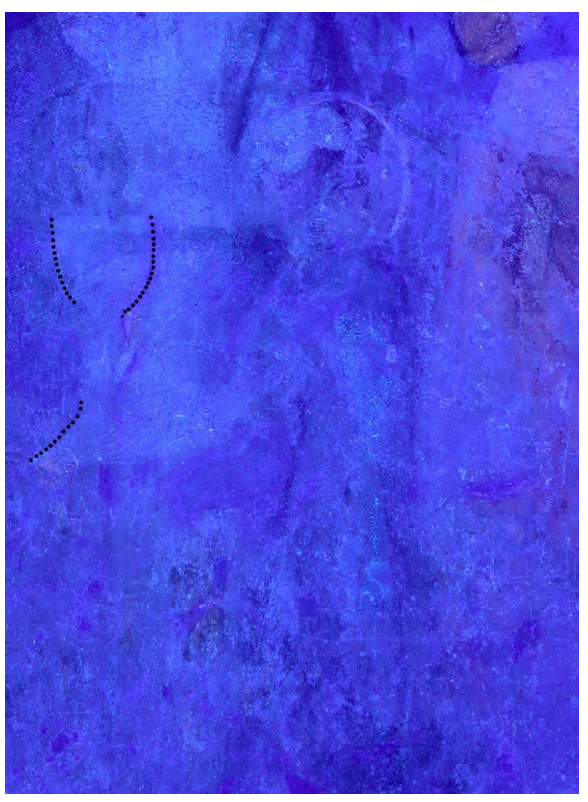

Il. 8. Toruń, kościół pw. Wniebowzięcia NMP, malowidło z Ukrzyżowaniem w nawie północnej, fragment: a - w bliskiej podczerwieni, b - we fluorescencji wzbudzanej UV. Widoczny zarys klęczącej pod krzyżem postaci świętego adoranta, kropkami oznaczono zarys kielicha. Fot. J. Raczkowski

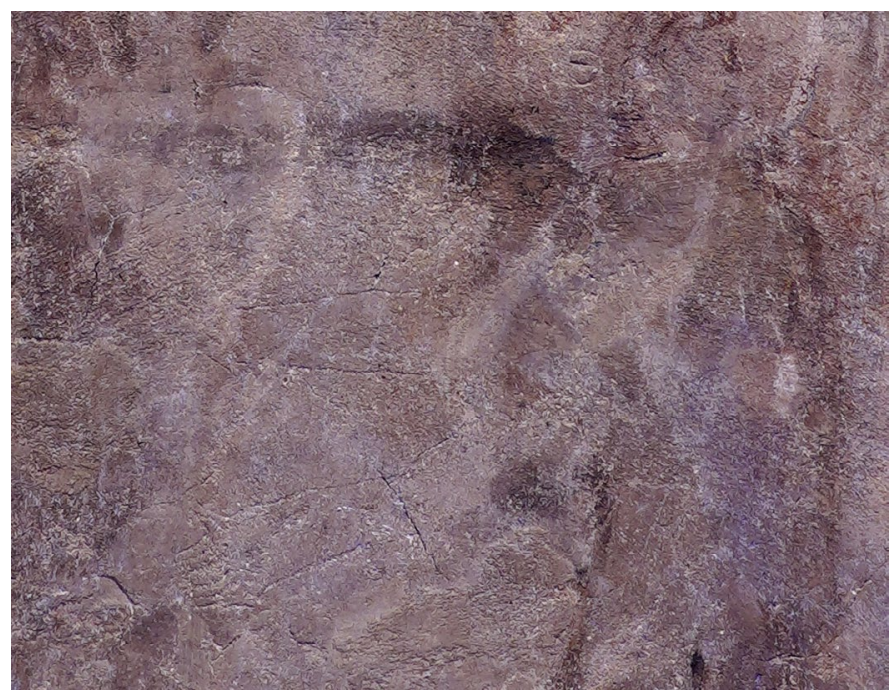

Il. 9. Toruń, kościół pw. Wniebowzięcia NMP, malowidło z Ukrzyżowaniem w nawie północnej, fragment - czytelny w świetle skośnym wyryty w tynku zarys rąk. Fot. J. Raczkowski 


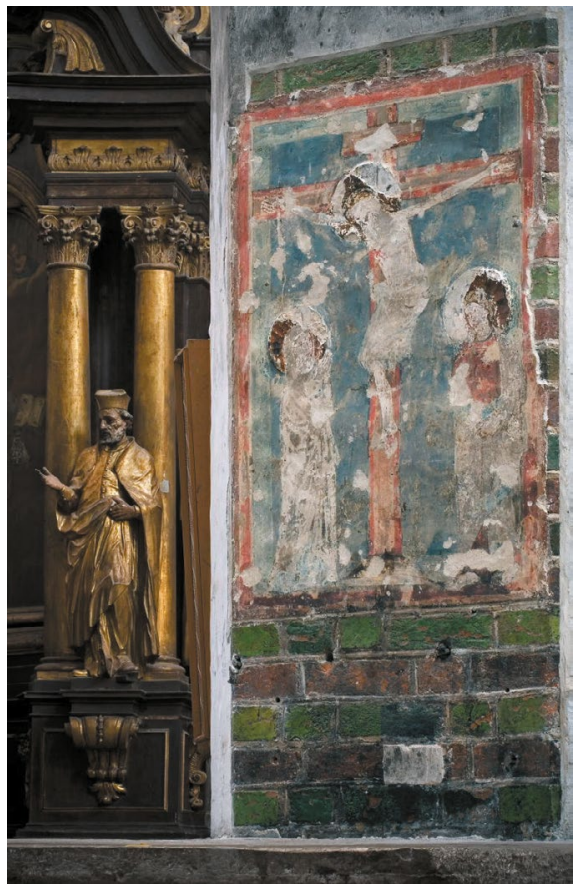

Il. 10. Toruń, kościół pw. św. Jana Chrzciciela i św. Jana Ewangelisty, malowidło z Ukrzyżowaniem na drugim filarze korpusu po stronie północnej. Fot. A. Cupa

a

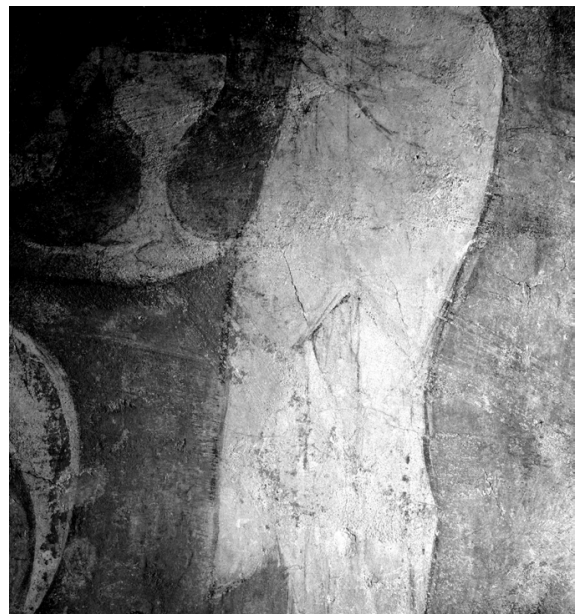

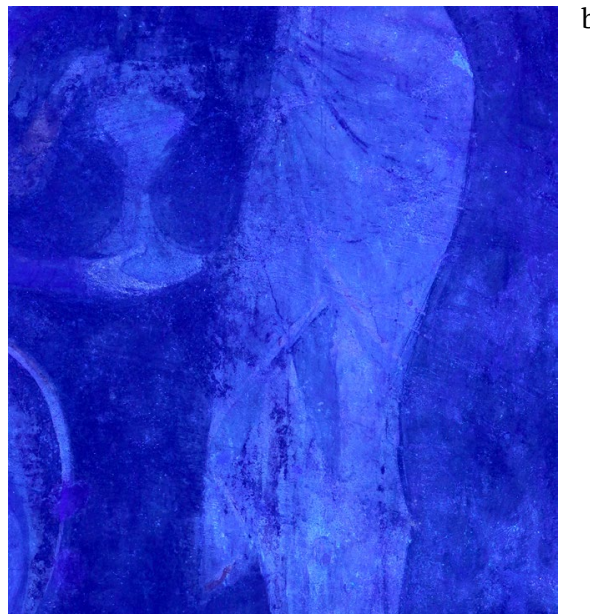

Il. 11. Toruń, kościół pw. Wniebowzięcia NMP, malowidło z Ukrzyżowaniem w nawie północnej, fragment - dolna część ciała Chrystusa: a - w bliskiej podczerwieni, b - we fluorescencji wzbudzanej UV. Fot. J. Raczkowski 
a

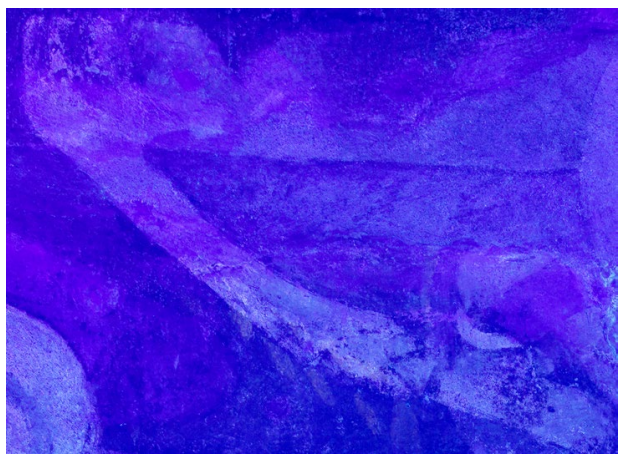

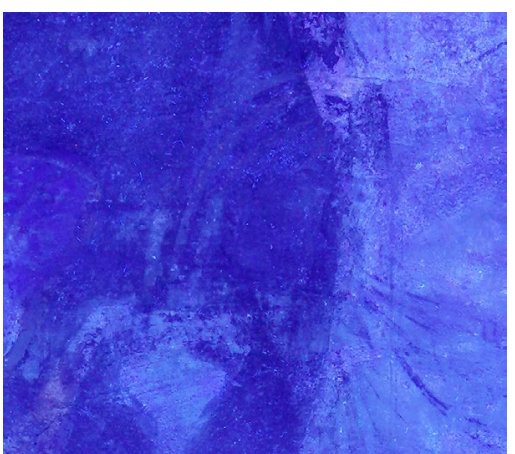

b

Il. 12. Toruń, kościół pw. Wniebowzięcia NMP, malowidło z Ukrzyżowaniem w nawie północnej, fragmenty we fluorescencji wzbudzanej UV z uwidocznioną krwią cieknącą z ran Chrystusa: a - z prawej dłoni, b - z rany w boku. Fot. J. Raczkowski

a
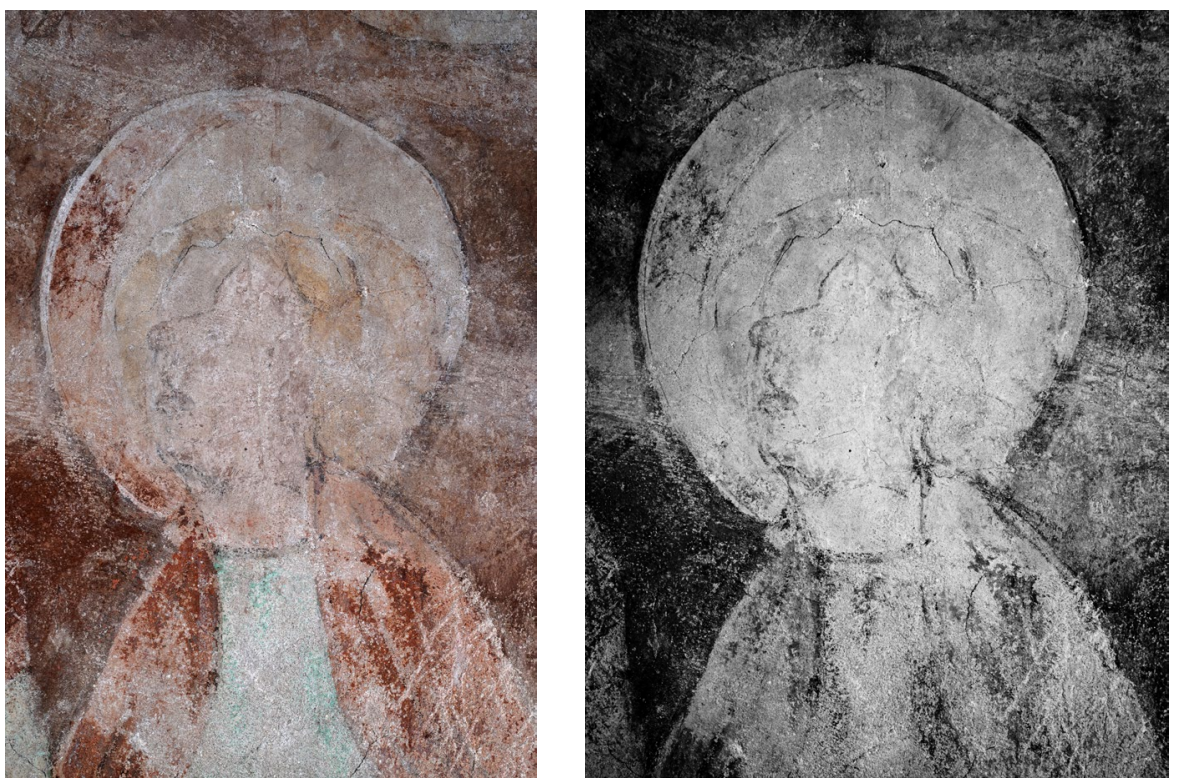

Il. 13. Toruń, kościół pw. Wniebowzięcia NMP, malowidło z Ukrzyżowaniem w nawie północnej, fragment - głowa św. Jana Ewangelisty: a - widok w świetle VIS, b - w bliskiej podczerwieni. Fot. J. Raczkowski 
a

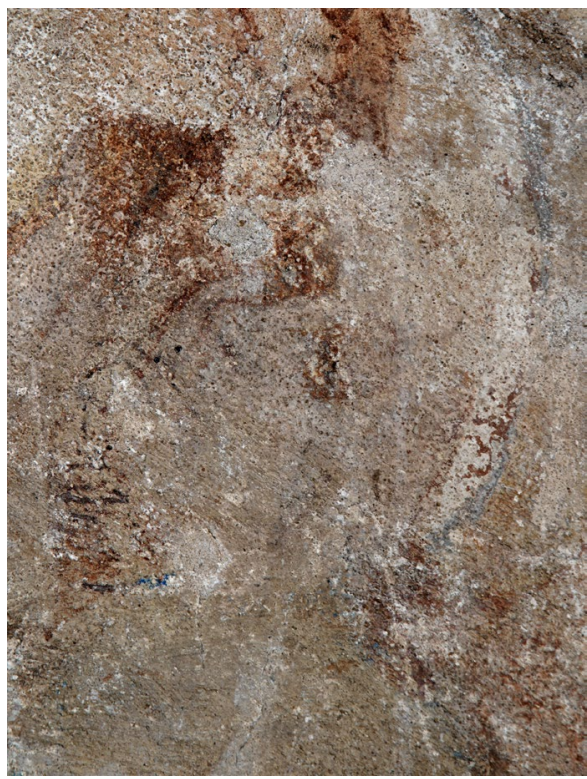

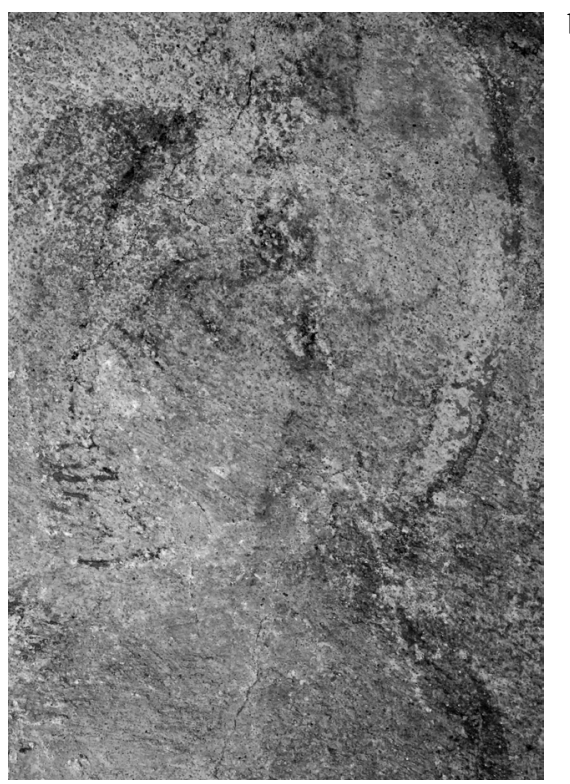

Il. 14. Toruń, kościół pw. Wniebowzięcia NMP, malowidło z Ukrzyżowaniem w nawie północnej, fragment - twarzyczka kobieca z niezachowanej postaci u stóp krzyża: a - widok w świetle VIS, b - w bliskiej podczerwieni. Fot. J. Raczkowski

a
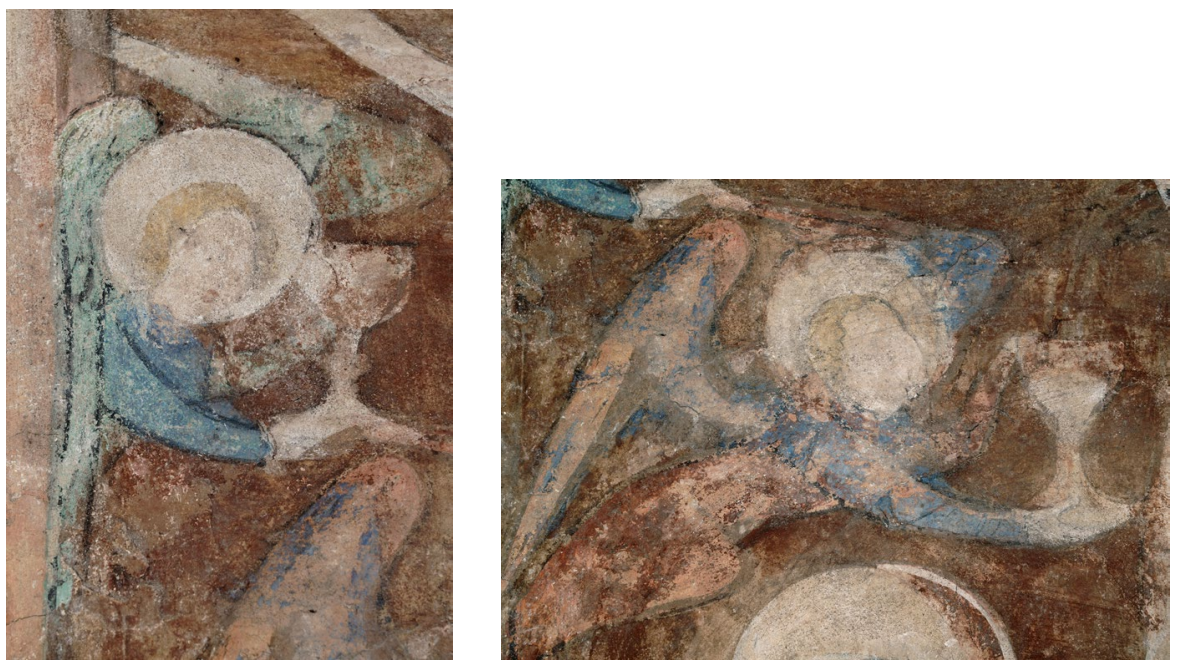

Il. 15. Toruń, kościół pw. Wniebowzięcia NMP, malowidło z Ukrzyżowaniem w nawie północnej: a, b - figury aniołów. Fot. J. Raczkowski 
[66]

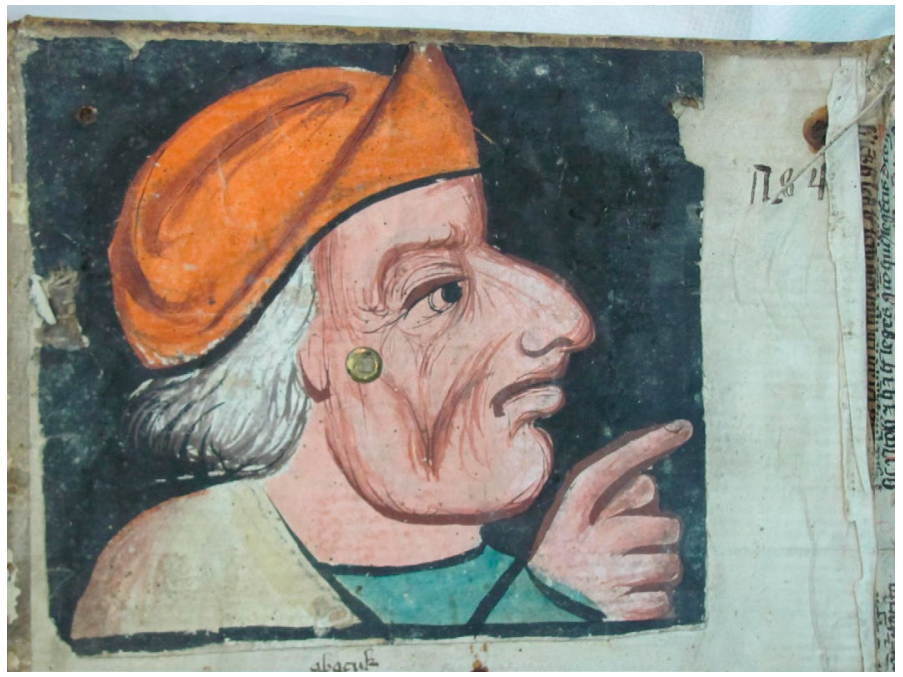

Il. 16. Głowa proroka Habakuka, miniatura na wyklejce kodeksu „Questiones Soltonis super IV sententiarium”, Biblioteka Uniwersytecka w Toruniu, sygn. 51/III. Fot. M. Jakubek-Raczkowska

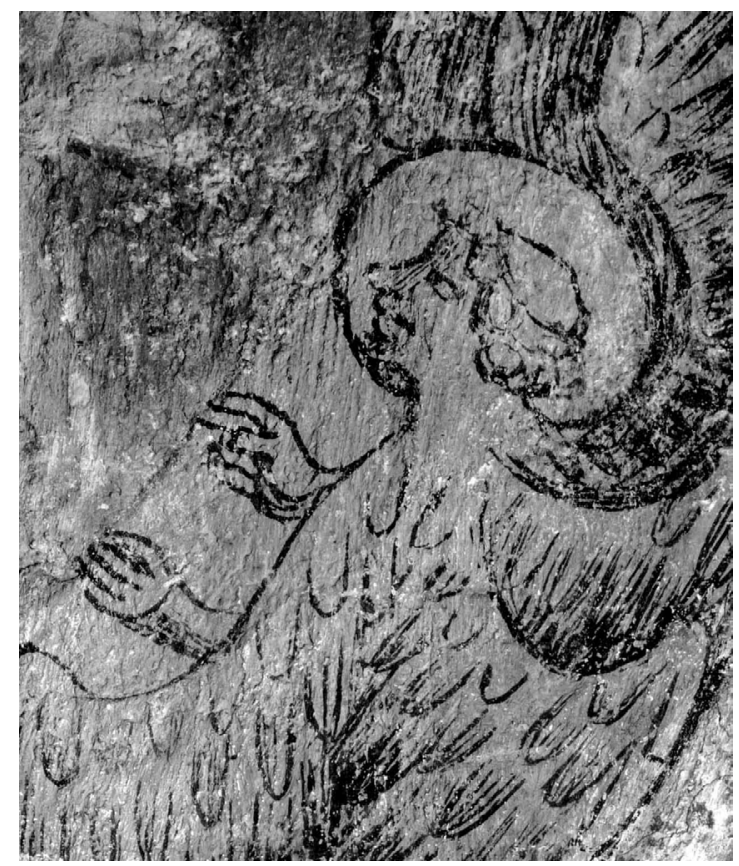

Il. 17. Toruń, kościół pw. Wniebowzięcia NMP, malowidło z Koronacją NMP w pierwszym od wschodu przęśle nawy południowej, fragment - główka anioła w bliskiej podczerwieni. Fot. J. Raczkowski 


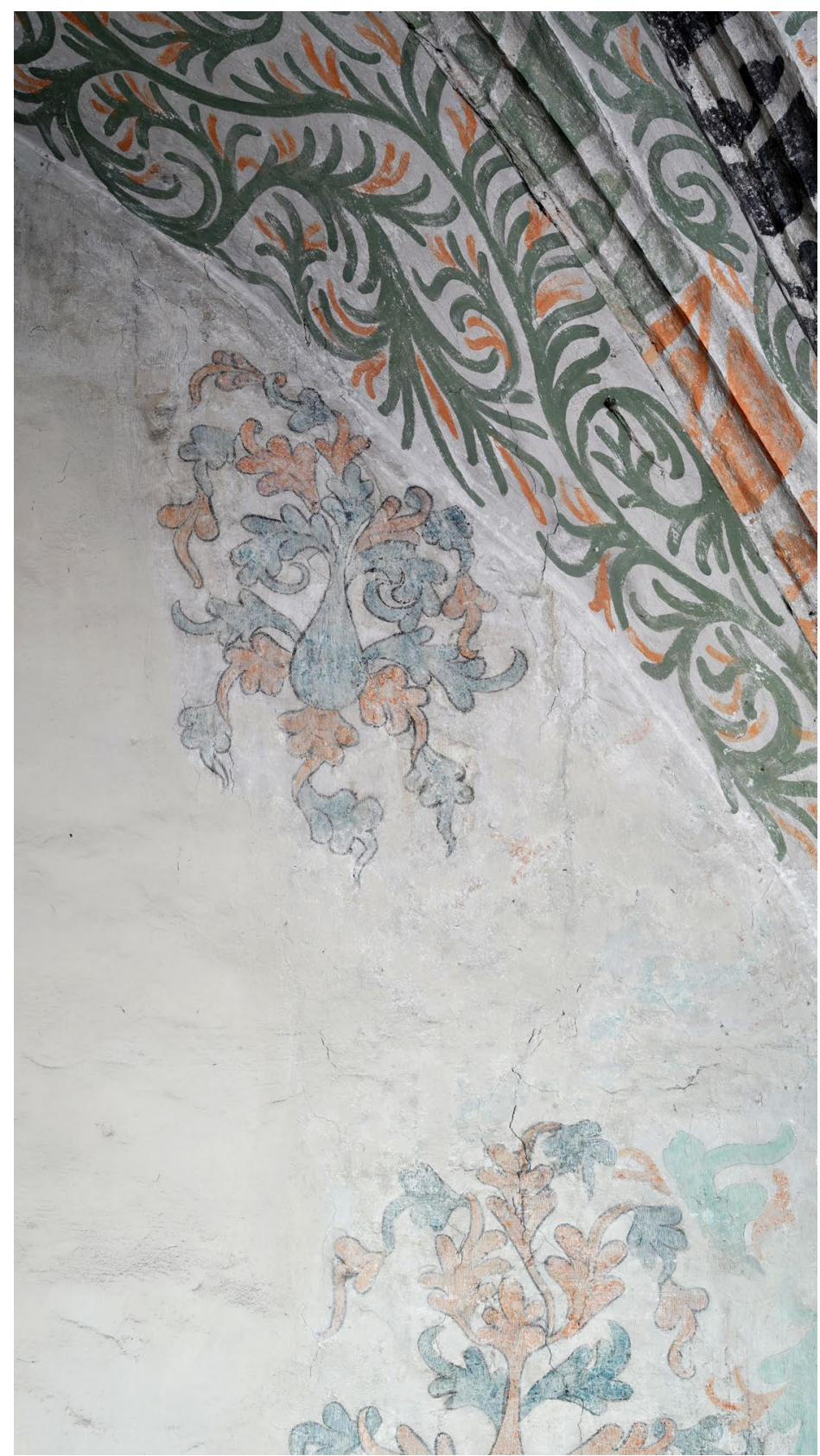

Il. 18. Toruń, kościół pw. Wniebowzięcia NMP, dekoracja sklepienia i ściany tarczowej w pierwszym przęśle od wschodu w nawie północnej. Fot. J. Raczkowski 


\section{Bibliografia}

Abegg, Regine. „Funktion des Kreuzgangs im Mittelalter: Liturgie und Alltag.” Kunst + Architektur in der Schweiz 48 (1997): 6-24.

Domasłowski, Jerzy. „Kościół Wniebowzięcia NMP w Toruniu.” W Malarstwo gotyckie $w$ Polsce (Dzieje Sztuki Polskiej 2, cz. 3), red. Adam Labuda i Krystyna Secomska. T. 2 Katalog, 103-104. Warszawa: DiG, 2004.

Domasłowski, Jerzy. „Polska północno-wschodnia.” W Materiały do katalogu gotyckich malowideł ściennych $w$ Polsce, red. Alicja Karłowska-Kamzowa, 41-61. Poznań: Wydawnictwo Naukowe UAM, 1981.

Domasłowski, Jerzy, i Jarosław Jarzewicz. Kościół Najświętszej Marii Panny w Toruniu (Zabytki Polski Północnej nr 10). Toruń: TNT, 1998.

Illi, Martin. „Der Kreuzgang als Bestattungsort.” Kunst + Architektur in der Schweiz 48 (1997): 47-55.

Jakubek-Raczkowska, Monika. „Tu ergo flecte genua tua”. Sztuka a praktyka religijna świeckich $w$ diecezjach pruskich państwa zakonu krzyżackiego do połowy XV wieku. Pelplin: Bernardinum, 2014.

Jakubek-Raczkowska, Monika, i Juliusz Raczkowski. „Dawny kościół Franciszkanów w Toruniu. Między regułą a tradycją miejsca / Ancienne église des Cordelières de Torun d'aprés des recherches récentes. Entre la régle et les besoins du lieu.” Referat na konferencji PTPN „Klasztor i kolegiata w średniowiecznej Europie”, Poznań, 9-12 grudnia $2020 \mathrm{r}$.

Jakubek-Raczkowska, Monika, i Juliusz Raczkowski. „Średniowieczny wystrój zespołu Wielkiego Refektarza na Zamku Średnim w Malborku.” W Wielki Refektarz na Zamku Średnim w Malborku. Dzieje - wystrój - konserwacja, red. Janusz Trupinda, 41-80. Malbork: Muzeum Zamkowe, 2010.

Jakubek-Raczkowska, Monika, Juliusz Raczkowski, i Tomasz Kowalski. Średniowieczne malowidła ścienne w kamienicach mieszczańskich Starego i Nowego Miasta Torunia. Medieval Wall Paintings in Burghers' Houses of the Old and New Town of Toruń. Toruń: TNT, 2017.

Marcinkowski, Wojciech. Przedstawienie dewocyjne jako kategoria sztuki gotyckiej. Kraków: Wydawnictwo i Drukarnia „Secesja”, 1994.

Meyvaert, Paul. „The Medieval Monastic Claustrum.” Gesta 12, Nr. 1-2 (1973): 53-59.

Mroczko, Teresa. Architektura gotycka na ziemi chełmińskiej. Warszawa: PWN, 1980.

Mroczko, Teresa. „Programy architektoniczne zakonów żebrzących na ziemi chełmińskiej w XIII i XIV wieku.” W Sztuka i ideologia XIV wieku w Polsce. Materiały sympozjum Komitetu Nauk o Sztuce PAN, Warszawa, 29 i 30 listopada 1973, red. Piotr Skubiszewski, 317-347. Warszawa: PWN, 1975.

Nawrocki, Zbigniew. „Kościół Mariacki w Toruniu - budowa i przebudowy w świetle odkryć w ostatnim ćwierćwieczu.” W Dzieje i skarby kościoła Mariackiego w Toruniu. Materiały z konferencji przygotowanej przez Toruński Oddział SHS przy współpracy In- 
stytutu Zabytkoznawstwa i Konserwatorstwa UMK, red. Katarzyna Kluczwajd, 19-53. Toruń: TNOiK, 2005.

Nawrocki, Zbigniew. „Pofranciszkański kościół NMP w Toruniu. Próba rekonstrukcji dziejów budowy." Zeszyty Naukowe Uniwersytetu Mikołaja Kopernika w Toruniu. Zabytkoznawstwo i Konserwatorstwo 2 (1966): 63-80.

Raczkowski, Juliusz. „Najnowsze odkrycia w zakresie gotyckiego malarstwa ściennego w Prusach i ich znaczenie dla badań nad sztuką regionu.” W Homo Creator et Receptor Artium. Księga pamiątkowa Księdzu Profesorowi Stanisławowi Kobielusowi ofiarowana, red. Małgorzata Wrześniak, 89-103. Warszawa: UKSW, 2010.

Silberer, Leonie. Domus fratrum minorum. Klosterbaukunst der konventualer Franziskaner vom 13. Jahrhundert bis zur Reformation (Studien zur internationalen Architektur und Kunstgeschichte 141). Petersberg: Imhof-Verlag, 2016.

Żankowski, Ryszard, i Krzysztof Owsiany. „Krużganek północny w kościele NM Panny w Toruniu. Spostrzeżenia i propozycje konserwatorskie. Program prac konserwatorskich, opracowano na zlecenie Konserwatora Miejskiego w Toruniu, Toruń, 2 kwietnia 1993 r.” Dokumentacja konserwatorska, Toruń 1993, Archiwum Biura Miejskiego Konserwatora Zabytków w Toruniu. 